\title{
The adventure of the deceitful numbers
}

\section{Melissa Andrade-Molina}

Abstract: This article addresses access to high-quality education under a neoliberal mentality. It engages at both the discursive and material levels, by mapping how taken-for-granted truths about neoliberal policies circulate through the media. The media-newspapers, network channels, and news websites-have correlated quality education with socioeconomic status, which have effects of power in the fabrication of the productive citizen and low-performer, and in the perpetuation of the "class/ room".

The unexpected deceitfulness of numbers operates as a rhizomatic regime of truths, conducting our ways of being and acting in the world. This analysis takes numbers as an actor to challenge the apparent representative and descriptive nature of standardized assessment outcomes, and the idea that competition, freedom of choice, and accountability are a means of securing equity, inclusion, and economic growth. The novels of Sir Arthur Conan Doyle, particularly those featuring the fictional character Sherlock Holmes, and the Sherlock Holmes adaptations portrayed by Benedict Cumberbatch in the TV series "Sherlock" have inspired the narrative of this story. Sherlock's mind palace-a feature added to Holmes' personality in the TV series-is put to great use in the narrative of this article.

Keywords: neoliberalism, governmentality, inequality, class/room, rhizome, freedom of choice.

"Here we are again. So many cases but none of them interest me. What happened to those good old mysteries? Patience! Keep calm and wait..."

R. G. is a consulting detective, much like the renowned Sherlock Holmes. R.G. did not enjoy solving crimes; finding the killer when everyone thought it was suicide had become trivial. He was not excited about anything anymore. 
He could feel he was losing his mind. Puzzles only appealed to him when he was able to show others the brilliance of his mind. He constantly felt part of a Scooby Doo type scene. Chasing felons-murderers, thieves, and villainsin an almost comical, boring monotony. He wanted to encounter a Professor Moriarty, the criminal mastermind who had earned the name of the "Napoleon of crime" or a Milverton, who had forced Holmes to wear the disguise of a plumber and become engaged to one of Milverton's housemaids. R.G. needed that feeling of facing a challenge.

"What else could I do, Dr. M?" said he.

"What would you like to do?" I asked.

"You have probably never heard of Professor Moriarty?" he looked at me. "A man of good birth and excellent education" he continued. "The man pervaded London, and no one had ever heard of him. That's what put him on a pinnacle in the records of crime." Of course I knew who Moriarty was, but I kept listening to R.G. "He was a mathematical celebrity, an expert on numbers. He was the organizer of half that was evil and of nearly all that was undetected in Sherlock's time. He was a genius, a philosopher, an abstract thinker. Like a spider he waited in the center of his web, but that web had a thousand radiations, and he knew every quiver of each of them. He did little himself. He only planned. But his agents were numerous and splendidly organized."1

"Is that what you need?" I proceeded.

"I do. I need a Moriarty"

"Then, you will like our next case." I stood and opened the door. "Please, come in." I said to her. "What is your name?" I asked.

"I'd rather not say," she said.

"Well, tell me why you are here? Go on!" said R.G.

She looked absolutely outraged. I could tell she was of good birth. Everything about her revealed it, her clothes, her makeup, her coiffure, her posture, the words she used, even her perfume. Everything! She had lots of papers in her hands. There were old newspapers mixed up with new ones, an old notebook, and other confusing documents.

"I am here to give you a case. The expensive of solving it is of no concern.

This is a past-tense adaptation of the dialog between Sherlock and Watson, describing the character of Moriarty in Adventure XI. The final problem, from The Memoirs of Sherlock Holmes by Sir Arthur Conan Doyle. 
I hold sufficient assets to employ your services, Mr. G." she commenced. "An impossible phenomenon has occurred." She continued. "And I want to get to the bottom of this deception." She pointed at her pieces of evidence.

"What are you pointing at?" I asked her.

She handed two news articles to R.G. "This is incorrect! Please, look at this!" We both look at the articles and read them carefully. We find no mistakes, nothing to be alarmed about. "It is impossible, don't you think?"

"Is that your great fraud?" He asked her, both confused and annoyed. I was perplexed. I could not see any fraudulent information. We had read the same article. "Please let yourself out. Good day."

"No! You are unable to comprehend what this means," she insisted.

"What is the problem?" I asked.

"Her problem is regarding the position of the schools in the table." R.G. replied to me, almost furious.

I took both papers and compared the tables on them. Oh, I see it now!

\begin{tabular}{|l|l|l|c|}
\hline & $\begin{array}{c}\text { Type } \\
\text { of } \\
\text { school }\end{array}$ & \multicolumn{1}{|c|}{ School } & $\begin{array}{c}\text { PSU } \\
\text { average } \\
\text { score }\end{array}$ \\
\hline 1 & Private & Cambridge College & 704.4 \\
\hline 2 & Private & Cordillera & 699.0 \\
\hline 3 & Private & Montemar & 694.0 \\
\hline 4 & Private & Internacional Alba & 693.4 \\
\hline 5 & Private & Los Andes & 692.9 \\
\hline 6 & Private & Instituto Alemán & 690.9 \\
\hline 7 & Private & Maimonides School & 689.7 \\
\hline 8 & Private & Pinares & 685.5 \\
\hline 9 & Private & San José & 683.7 \\
\hline 10 & Private & The Grange School & 682.6 \\
\hline$\ldots$ & & & \\
\hline 34 & Public & Liceo Augusto & 665.0 \\
\hline
\end{tabular}

\begin{tabular}{|l|l|l|c|}
\hline & $\begin{array}{c}\text { Type } \\
\text { of } \\
\text { school }\end{array}$ & \multicolumn{1}{|c|}{ School } & $\begin{array}{c}\text { PSU } \\
\text { average } \\
\text { score }\end{array}$ \\
\hline 1 & Private & Cambridge College & 714.3 \\
\hline 2 & Private & Cordillera & 700.7 \\
\hline 3 & Private & Itahue & 698.5 \\
\hline 4 & Private & Tabancura & 697.5 \\
\hline 5 & Private & Albamar & 691.2 \\
\hline 6 & Private & The Grange School & 687.4 \\
\hline 7 & Private & Alemán de Concepción & 658.4 \\
\hline 8 & Public & $\begin{array}{l}\text { Liceo Augusto } \\
\text { D'Halmar }\end{array}$ & 682.9 \\
\hline 9 & Private & La Girouette & 680.9 \\
\hline 10 & Private & $\begin{array}{l}\text { Lincoln International } \\
\text { Academy }\end{array}$ & 679.5 \\
\hline
\end{tabular}

*Rankings of top 100 schools in 2016

${ }^{* *}$ Rankings of top 100 schools in 2017

What was her problem? I thought. The documents she had brought were reports made by a network channel, T13. The "fraud" was that the first public school had ranked in $34^{\text {th }}$ place in 2016 and $8^{\text {th }}$ in 2017 , based on the

\footnotetext{
* Available at: http://www.t13.cl/noticia/nacional/te-puede-servir/ranking-colegios-mejor-promedio-psu-2016

** Available at: http://www.t13.cl/noticia/nacional/el-ranking-colegios-mejor-puntaje-promedio-psu-2017
} 
PSU results. "PSU?" I had never heard of it. I looked it up. "Chilean Universal Admission Test, do you know what this is?" I asked R.G.

"Tell me," he said. So, I proceed to read aloud what I had found out.

"PSU is a battery of four standardized multiple-choice tests designed to assess academic readiness for college and used to select applicants to universities in Chile, bla, bla, bla. Wait, this is important. The PSU has been developed to reflect the high school curriculum and closely approximates the skills needed for academic success at the university level. Since 2014, the PSU takes into account the Fundamental Objectives and Mandatory Minimum Contents (in Spanish: Contenidos Minimos Obligatorios - CMO), which describe the knowledge and skills that students should be able to demonstrate in high school. There are certain CMOs not included in the PSU because they relate to the development of more complex skills that are difficult to measure using standardized assessments, such as the ability to work in group projects, computing management, and conducting experiments, among other skills"2.

He turned towards her and said, "A test to select the best students to access universities. Is that your problem? You do not think they are qualified enough to be considered "the best" students."

"Well, they do not pay for their education. All of them want everything for free. They do not work, and, therefore, they do not deserve it. This is not right!" she said.

“Are you talking about meritocracy? Please, leave!" he said.

"That is the only public school that ranked amongst the best!" she said.

R.G. stopped. He stood still. "What did you say?"

"That school is a fraud!"

"Interesting" he said. "I will take the case. Please, get out now, and hand your evidence to M.!"

She seemed disturbed by R.G.'s tone. Although, he was also disturbed by hers. She left, and both of us proceeded to read the papers she had brought with her. They were media reports.

"Have you noticed it?"

"Noticed what, R.G.?"

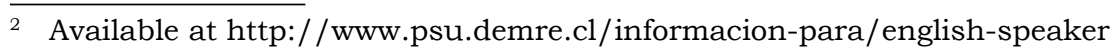


"You see, but you do not observe. The distinction is clear," he said. "The public school ranked $8^{\text {th }}$. Did you look at the 2016 positions? Only three schools remained in the top seven positions. But four of them moved. The $5^{\text {th }}$ is now $22^{\text {nd }}$. The $6^{\text {th }}$ is now $26^{\text {th }}$. The $7^{\text {th }}$ is now $37^{\text {th }}$. But the $4^{\text {th }} \ldots$ the $4^{\text {th }}$ is now $46^{\text {th }}$. Her child must attend one of these four schools. If not, she is disgusted by the idea of public schools ascending and private, highly expensive fee-paying schools descending"

I glanced at the rankings one more time. "You are right!"

\begin{tabular}{|l|l|l|c|}
\hline & $\begin{array}{c}\text { Type } \\
\text { of } \\
\text { school }\end{array}$ & \multicolumn{1}{|c|}{ School } & $\begin{array}{c}\text { PSU } \\
\text { average } \\
\text { score }\end{array}$ \\
\hline 1 & Private & Cambridge College & 704.4 \\
\hline$\ldots$ & & & \\
\hline 4 & Private & Internacional Alba & 693.4 \\
\hline 5 & Private & Los Andes & 692.9 \\
\hline 6 & Private & Instituto Alemán & 690.9 \\
\hline 7 & Private & Maimonides School & 689.7 \\
\hline 8 & Private & Pinares & 685.5 \\
\hline 9 & Private & San José & 683.7 \\
\hline 10 & Private & The Grange School & 682.6 \\
\hline$\ldots$ & & & \\
\hline 34 & Public & $\begin{array}{l}\text { Liceo Augusto } \\
\text { D’Halmar }\end{array}$ \\
\hline
\end{tabular}

Rankings of top 100 schools in 2016

\begin{tabular}{|l|l|l|c|}
\hline & $\begin{array}{c}\text { Type } \\
\text { of } \\
\text { school }\end{array}$ & \multicolumn{1}{|c|}{ School } & $\begin{array}{c}\text { PSU } \\
\text { average } \\
\text { score }\end{array}$ \\
\hline 1 & Private & Cambridge College & 714.3 \\
\hline$\ldots$ & & & \\
\hline 8 & Public & $\begin{array}{l}\text { Liceo Augusto } \\
\text { D'Halmar }\end{array}$ & 682.9 \\
\hline$\ldots$ & & & \\
\hline 22 & Private & Los Andes & 673.1 \\
\hline$\ldots$ & & & 670.8 \\
\hline 26 & Private & Instituto Alemán & \\
\hline & & & 665.2 \\
\hline 37 & Private & Maimonides School & \\
\hline$\ldots$ & & & 661.4 \\
\hline 46 & Private & Internacional Alba & \\
\hline
\end{tabular}

Rankings of top 100 schools in 2017

"How do you think she drew those conclusions? There is something beyond what she is able to see. This has "Moriarty" written all over it!"

"That is why you took the case," I said. "But you know Moriarty is a fictional character, right?"

"Do you think this is the work of one person?" he said. "Chile, my dear M, has a competitive and selective education system that is highly segregated with strict social stratification occurring from early childhood education and care through to tertiary education". . He took one of the documents. "I assume you also forgot to look at this ranking, Dr. M."

Before me was a newspaper report: How much does it cost to study at a school with a higher PSU score? It showed rankings produced by a news-

3 Holmes to Watson in A Scandal in Bohemia, from The Adventures of Sherlock Homes by Sir Arthur Conan Doyle.

4 (Aravena \& Quiroga, 2017, pp. 121-122). 
paper, El Mercurio, on the cost of attending preschool year at the "best" schools. The classifications had been made according to the performance of 17-18 year old students on the PSU, and correlated not with the cost of the last year of school, but with the cost of the preschool year. Now I understood R.G.'s point.

\begin{tabular}{|l|l|c|c|c|c|}
\hline $\begin{array}{c}\text { PSU } \\
\text { score }\end{array}$ & \multicolumn{1}{|c|}{ School } & $\begin{array}{c}\text { Admission } \\
\text { fee USD* }\end{array}$ & $\begin{array}{c}\text { Enrollment } \\
\text { fee ISD }\end{array}$ & $\begin{array}{c}\text { Tuition fee } \\
\text { USD }\end{array}$ & $\begin{array}{c}\text { Total Cost } \\
\text { USD }\end{array}$ \\
\hline 714.3 & Cambridge College & 1022.99 & 466.46 & 4332.60 & 5822.05 \\
\hline 700.7 & Cordillera & 4003.00 & 667.17 & 7890.35 & 12560.52 \\
\hline 698.5 & Itahue & 845.08 & 480.36 & 4803.59 & 6129.03 \\
\hline 697.5 & Tabancura & 4003.00 & 667.17 & 7890.35 & 12560.52 \\
\hline 691.2 & Albamar & 2001.50 & 408.80 & 4007.97 & 6418.27 \\
\hline 687.4 & The Grange School & 8005.98 & 533.73 & 10407.78 & 18947.49 \\
\hline 687.0 & Alemán de Concepción & 2207.80 & 481.40 & 4814.00 & 7503.2 \\
\hline 682.9 & Liceo Augusto D'Halmar & 0 & 0 & 0 & 0 \\
\hline 680.9 & La Girouette & 2668.66 & 336.98 & 5014.86 & 8020.5 \\
\hline 679.5 & Lincoln International Academy & 5337.33 & 533.73 & 6582.70 & 12453.76 \\
\hline & Average & 3009.53 & 457.58 & 5574.42 & 9041.53 \\
\hline
\end{tabular}

The admission fee is paid only once, when the student is admitted to the school*

"This, M., challenges the free choice promise of the neoliberal system," he continued. "These numbers are an actor that produces things through processes that seem to be merely representing and describing ${ }^{5}$. This woman was just repeating all she has read in the media. Low-income students are not disadvantaged per se, they become disadvantaged," he paused. "System of reason, of course!"

"What system? R.G.?" I asked, but no answer was given. He was in his mind palace. All the information he could grasp was gathering in his head. A technique he had acquired while reading Sherlock's brain attic ${ }^{6}$. I just had to wait.

"Oh, I see it now!" said he after a while. "Numbers are a social technology that seems to instantiate a consensus and harmony in a world that appears, otherwise, uncertain, ambiguous, and contentious... By correlating the statistical magnitudes of these characteristics of populations to achievement levels of children, it is thought that a more equal and democratic society can be

\footnotetext{
* Available in Spanish at: http://impresa.elmercurio.com/Pages/NewsDetail.aspx?dt= 27-12-2017\%200:00:00\&NewsID =539894\&dtB=27-12-2017\%200:00:00\&BodyI$\mathrm{D}=2 \&$ PaginaId $=4$

5 (Popkewitz, 2015a, p. 151).

6 The brain as an attic is addresed in A Study in Scarlet, by Sir Arthur Conan Doyle.
} 
achieved ${ }^{7}$," he continued. "But the making of equivalencies embodies comparability that creates differences from some sameness that differentiates and divides in the impulse to include ${ }^{8}$."

"What?" I did not possess the amount of information he had gathered over the years. I was both amazed and perplexed.

"Simple! They have said over and over that the test reveals inequalities of the school system ${ }^{9}$. However, these types of large-scale assessment are the main producers of those inequalities. It is not only because of the tests; it is because of the readings on the outcomes, the classifications. It is because the system of reason unfolds rhizomatically ${ }^{10}$ across every branch of human interaction. These numbers are making kinds of people ${ }^{11}$ ! The discursive formation of neoliberalism is shaping the current governmentality controlling education ${ }^{12}$."

"So you have solved it, then?"

"At least I have got a grip of the essential facts of the case. I shall enumerate them to you. And I can hardly expect your co-operation if I do not show you the position from which we start ${ }^{13}$," he said. "The goal of the existing policies in Chile is to overcome poverty, using ideas such as the pursue equity, quality, and efficiency."

"Yes. To help close the gap between income and achievement"

"As they promised. But, contrary to the expectations of the reformers, quality education has not brought the equality promised or the integration of students into the so-called path to modernity ${ }^{14}$," he said.

"I see!"

"And the insistence on the neoliberal principle of efficiency, with the exclusion effect it creates, has ended up contributing to a division between school performance and student's culture ${ }^{15}$," he continued. "And this division created by neoliberal reforms led to low-income students being perceived not

\footnotetext{
(Popkewitz, 2015a, p. 152).

(Popkewitz, 2015a, p. 150).

9 (see Miranda, 2017; Carrasco \& Urrejola, 2017; Elacqua, Martínez, Santos \& Urbina, 2016).

10 (Deleuze \& Guittari, 1987).

11 (Popkewitz, 2015a).

12 (Kaščák \& Pupala, 2011, p. 147).

13 Holmes to Watson in Adventure I. Silver Blaze, from The Memoirs of Sherlock Holmes by Sir Arthur Conan Doyle.

14 (Cavieres, 2011, p. 121).

15 (Cavieres, 2011, p. 122).
} 
only as in need of salvation, but, as subordinate, passive, and weak $k^{16}$ at the same time".

"The same reforms that are aimed at equity, wellbeing, and social mobility are perpetuating the portrayal of the problematic low-income child," I said.

"This portrayal, my dear Dr. M., has led the reformers to relativize the effect of existing economic inequalities over impoverished students and to consider their low performance as a result of personal and psychological problems ${ }^{17}$," he added. "This discourse is not only found amongst reformers, it circulates in the media, national policy documents, among people. The woman used the same words."

"Low-income students are then perceived as cognitively deficient."

"I assume you also missed this report the woman brought," he handed me a piece of paper.

It was a report from El Dinamo entitled " 3 out of 10 students do not achieve the minimum score needed to apply to university" 18 . Of course that is alarming, $30 \%$ of students were not going to be able to pursue higher education.

"Did you notice?" he asked me.

Did I notice? What was I looking for? This report had little information in it, only numbers with no deeper analysis. "It says that the highest scores are achieved by private schools and that schools that did not achieve the minimum score were public or private/subsidized schools."

"Exactly. The information about the private schools becomes an advertisement. "They do not fail, they produced the best". But even if paid for, the analysis reveals its failures. It says, the majority of low scores belonged to private/subsidized and public schools, but not all of them. This report does not indicate that more than 2,000 of the low achieving students come from private schools, which are portrayed as flawless. Which is roughly 1 out of every 100 students."

I paused and looked at the document again. "Of course. It would be completely the opposite if the title of the report had been Private schools are not always the best choice: 1 out of 100 students taking the tests do not achieve the minimum score needed to apply to university. I assume that reading PSU outcomes in that way would be bad publicity on the trustworthiness of the

16 (Rambla \& Verger, 2009).

17 (Cavieres, 2011, p. 123).

18 Available at: http://www.eldinamo.cl/educacion/2017/12/26/psu-2017-3-de-cada10-estudiantes-no-logra-el-puntaje-minimo-para-postular-a-la-universidad/ 
private system," I said. I reread the document. "They also forgot to mention how many students from private/subsidized and public schools are high achievers," I added.

"What about here?" he continued.

He showed me an Emol report, entitled More than 50 students obtained 150 points, the test's minimum score ${ }^{19}$. "Fifty-two students got the lowest score. And one of them attended a private school," said I. "Which means that one of the private school students will achieve the lowest test outcome. Although 27 from public schools, and 24 from private/subsidized schools is much more statistically significant." After all, 1 out of the 265,113 students that took the test is practically zero.

"If only it were that simple, my dear M. In the U.S., in the state of Georgia, two out of three students from low-income families failed the mathematics, English and reading tests, while all the students from wealthy families were successful ${ }^{20}$ The low-performer is problematic not because students are failing, but because they are fabricated to be low-performers. They are aware that, compared to students from other schools coming from wealthier neighborhoods, they have much less possibilities for succeeding in life. As a result, they do not feel committed either to their studies or their high schools, creating in them a sense of hopelessness that they will not be able to go on to higher education or be hired in well-paid jobs ${ }^{21}$. And all these media reports, that are easy to access, that are free to share, are perpetuating these taken-forgranted truths."

"What a dilemma, R.G.! Education is considered the path towards economic equity ${ }^{22}$, and at the same time, education is becoming a consumer good for an ever-growing economy ${ }^{23}$."

"No, M. Education has become an investment. Investment in quality education and care for future economic development and social returns has been mobilized as the dominant global educational reform rhetoric ${ }^{24}$. The investors have become the consumers of a highly marketable product that will guarantee a better future, and those unable to invest... are subjected by the low-performer discourses."

19 Available at: http://www.emol.com/noticias/Nacional/2017/12/27/888985/PSU2017-52-estudiantes-obtuvieron-el-peor-resultado-en-la-prueba.html

20 (Minarechová, 2012, p. 89),

21 (Cavieres, 2011, pp. 123-124).

22 (Carrasco \& Urrejola, 2017).

${ }^{23}$ (see Andrade-Molina, 2017a; Wilkins, 2012). And an example from mathematics education in Andrade-Molina (2017c).

${ }^{24}$ (Lee, 2012, p. 30). 
"What about the investment in education made by countries. Voucher systems have been created for those unable to access paid education," I asked.

"Indeed. First, preschool vouchers amplify socio-economic differences and sustain or even further perpetuate the existing status quo for children and their families. Second, such a false hope about vouchers is a global phenomenon and is associated with the limitation of neoliberal policies for their inabilities to challenge deeper social inequalities with an economic rationality." 25

"And those programs in early child care education. Are they not of interest also, given that child care education is understood as a major part of education $^{26 ? "}$

"Dear Dr. M., despite the common-sense and good intentions, in Chile there is an urgency to integrate the country into the international markets, and acquire a business-like culture based on individualistic practices of consumption, as lived in developed countries. And people excluded from this model tend to assume some cultural behaviors of their own. In contrast to the entrepreneurial spirit of modernity, exclusion creates among low-income groups a feeling of fatalism according to which nothing they can do or plan will allow them to improve their economic position ${ }^{27}$."

"PSU tests only help make these social disparities more visible, and reproduce them in higher education. The high-income students have the advantage of being able to access university ${ }^{28}$, not solely because they can afford it, but also because they obtain the necessary scores to gain access to a more selective institution, for example public universities," said I. "Oh! Are public universities not less expensive than private ones? Interesting."

"Do you see how it makes sense to use those types of correlation between highly paid preschools and high outcomes in large-scale testing? The parents, as consumer, read these reports and understand that the safest option is to pay for a school with the highest ranking they can afford," he continued. "Policies under neoliberalism, Dr. M., promote the privatization of the economy, and even those institutions that remain public are shaped into following a business-like model based on competition and strict accountability to improve the goods and services they offer ${ }^{29}$."

\footnotetext{
25 (Lee, 2012, p. 36).

26 (Aravena \& Quiroga, 2017, p. 126).

27 (Cavieres, 2011, pp. 116).

28 (Miranda, 2017).

29 (Cavieres, 2011, p. 113).
} 
"Education is not only an investment for parents. It is not about economic equity. It is not about giving students higher quality..." I stopped. Astonished. Everything started moving around me. Turning. Speeding. I could not control my breathing. Speechless. He had managed to see all this in just a second. Moriarty. That was it. It had Moriarty written all over it!

"Do you see it now?" he asked.

"I cannot comprehend why. I mean, how. What for?"

"All the facts are here, there, everywhere, in front of us. On the surface," he stood and picked up his pipe while walking to the window. "Dear M., an important policy in Chile on school funding made it possible to allocate funding to public schools according to the number of students enrolled. Private schools were also allowed to apply for this funding in exchange for not charging high fees to students. The Chilean education system became integrated by public schools, private/subsidized schools, and elite private schools that opted to continue charging high fees and attending high-income families instead of receiving the state subsidy ${ }^{31}$. I assume you can tell where I am going with this".

"It guarantees prestige. Private schools are able to select and attract students," said I.

"They do not hide it. It is public information, accessible for free. And the media love comparisons," he handed me another report the woman had brought.

"Well, it is what it sells the most. Scandals!" I added. I looked at the news from El Dinamo. How much does it cost and what are the requirements of the 10 schools with higher PSU scores ${ }^{32}$. "Are they the best because they only admit the best candidates?" I asked him.

"Well, M. by stating who is a suitable candidate, the private schools are also saying, who is not. There are double gestures ${ }^{33}$. They are asking for grades for up to three years before the application date, stating a minimum requirement of 5.5 on a scale from 1 to 7 . They ask for personality tests reports, maturity tests, admission tests, letters stating the expectations of the applicant. They also schedule an interview with the parents. One school even asks for recommendation letters from someone associated with the

${ }^{30}$ (Deleuze, 1990).

31 (Cavieres, 2011, 177).

32 Available at: http://www.eldinamo.cl/educacion/2017/12/26/cuanto-cuestan-yque-piden-los-10-colegios-con-mejores-resultados-psu-2017/

33 (Popkewitz, 2009). 
school. Can you tell who will be unsuitable for those highly ranked private schools?"

"Yes. It is easier to find a job than to apply to one of those schools," I said with irony and hesitation. In front me... was Moriarty. Not in the flesh. Not the fictional character from Sherlock Holmes. There was a system of reason that ordered the common sense of schooling embodying comparative principles that exclude and abject in the impulse for equality and inclusion ${ }^{34}$.

"It would be easier to charge an exorbitant fee for applying to those schools. Money is not all they want. It is not about profit. It is an incepted regime of truth ${ }^{35}$. There is more here than just hope and fears; it is about fabricating productive citizens through the technologies of the self $f^{36}$, my dear M."

"So, people are governed by and through their own interests ${ }^{37}$ or non-interests. In this case, the pursuance of higher education. Right?"

"Do not forget. Any evaluation, such as the PSU or another type of standardized testing, represents a means of exclusion that transcends sectors and institutions. It allows and legitimizes inclusion by exclusion ${ }^{38}$."

"Ah! The deceitful number is the average PSU result obtained by the public school amongst the best ten schools, the only public one amongst the highly paid ones. It does not show cultural differences, but how well the perversions of the system work!" said I.

"Careful. There are no perversions. It is a paradox of the educational policy of the OECD being the flag ship of the main protagonists of humanist education battling against the consequences of economic globalisation, individualism and consumerism ${ }^{39}$. Students are submerged into a regime of individualism, competition, and consumerism. It is a set of taken-for-granted truths that have historically circulated in different times and places. Like wormholes connecting multiverses ${ }^{40 "}$

"Those reforms have helped shape the way people are to act, think, and feel about the world ${ }^{41}$, if there are no perversions, why the exclusion, R.G.?"

\footnotetext{
34 (See Popkewitz, 2015b, p. 13).

35 (See Andrade-Molina, 2017c).

36 (Foucault, 1988).

37 (Cotoi, 2011, p. 113).

38 (Höhne, 2006, p. 216).

39 (Kaščák \& Pupala, 2011, p. 151).

40 (Andrade-Molina, 2017b).

41 (Dussel, 2003, p. 94).
} 
"Indeed, it does this through the regulated choices of individual citizens, now constructed as subjects of choices and aspirations to self-actualization and self-fulfilment ${ }^{42}$," he said. "Who we are and how we should be to become autonomous and productive selves are internally desired by ourselves rather than externally required. This alteration concerning how we are governed while we simultaneously become self-disciplined as we accept the economic rationalities through neoliberal policies as the "norms" and "truths" is a significant effect of neoliberalism ${ }^{43}$."

"Then, parents are free to choose the type of school and education program they want for their children ${ }^{44}$. Regulated choices and aspirations... So life is to become a continuous economic capitalization of the self $f^{45}$."

"My dear M., schools have been taken, since the beginning, as the place where people can develop the skills needed for their own life, as the place where people can be free to choose whatever path they would want to take in life. It had been thought to possess a pastoral faculty able to rescue people from their destiny ${ }^{46}$. What this woman did was not to voice her own discomfort, but to reveal a regime of truth, a system of reason that permeates even low-performers. The discussion is not about their skills and cognitive abilities. It is about naturalized truths navigating their way through every discourse about the limited opportunities low-income students have and will have. It is about the dominant narratives that portray them as the failures of the system."

"They are caricatured as demanding high quality education for free because they do not want to pay for school ${ }^{47}$ and their families do not want to work, the law of the minimum effort as they called it ${ }^{48}$," I said.

"There exists the belief that by introducing more privatization, schools will have to improve because they will have to compete for students, while also arguing that parents will have more freedom to choose the best school for their children due to this competition. However, the lower- and middle-class students cannot choose, because the system is private and elitist ${ }^{49 \prime}$, said he.

42 (Rose, 1996, p. 41).

43 (Lee, 2012, p. 37).

44 (Mizala \& Romaguera, 2000).

45 (Rose, 1999, p. 161).

46 (Andrade-Molina, 2017b, p.61).

47 An example of this can be seen here: http://www.diarioelheraldo.cl/noticia/josepinera-en-chile-la-gente-quiere-todo-gratis

48 An example of this can be seen here: https://www.cronicachile.cl/2017/11/02/ chilecorrupcion/jose-antonio-kast-sin-pelos-en-la-lengua-si-quieren-todo-gratis-sinminimo-esfuerzo-no-voten-por-mi/

49 (Cabalin, 2012, p. 223). 
"And so M., school choice is seen as a key mechanism for driving school improvement and developing a competitive meritocracy ${ }^{50}$."

"The free choice market becomes an illusion, R.G."

"The only thing that is not a choice is making choices!" " he said. "The intricate network which has been created within education, through the extension of neoliberalism, has established a specific discourse regime for the different levels of education, creating an education system that is now run along homogenised neoliberal lines ${ }^{52}$. In school, these homogenizing lines enable us to assume that social, economic, and cultural differences can be minimized or erased if all students are educated under the same opportunities. Then, the students are the only ones responsible for their own failure or success in school, in the tests, and in their future."

"A technology of schooling?” asked I.

"Indeed. Technologies of schooling are hybrid, heterogeneous, traversed by a variety of programmatic aspirations and professional obligations, a complex and mobile resultant to the relations amongst persons, things and forces ${ }^{53}$. These technologies shape student subjectivities by normalizing and regulating who a productive citizen is, should be, and how is to act. The deceitful numbers are not just figures that can be correlated. Numbers, as an actor entail cultural theses about modes of living that govern what is possible and not possible ${ }^{54}$."

"I see it now. Education fabricates productive citizens for future growth," said I. "Although, it is quite unfair. How are low-income children supposed to study? They would probably have to share a room, with no space in which to study, just a tiny house. Equality? Are those the equal opportunities for education? Doubtful! They are probably not even interested in taking the test, but want to find a job. Twelve years of compulsory education is all they need. A diploma. Is tertiary education a priority for them?" I continued. "For high-income families it is normal to apply to university and obtain a professional diploma, maybe two, and not have to bother working... yet ${ }^{55}$. Those that do not go to university are the odd ones out. At least it is an option. For low-income families the average young person will work. In fact, it is odd if they go to university and pursue higher education. On what income? Under

50 (Brooks, 2017, p. 758).

51 (Popkewitz, 2015, p. 158).

52 (Kaščák \& Pupala, 2011, p. 152).

53 (Rose, 1999, p. 54).

54 (Popkewitz, 2015a, p. 159).

55 An example of this can be seen here: http://www.eldesconcierto.cl/2017/12/19/eltestimonio-de-una-chilena-de-clase-acomodada-que-refuta-la-idea-de-que-ser-ricoes-producto-del-esfuerzo/ 
what conditions? ${ }^{56}$ Most likely, those going to college would have to find part-time jobs to cover tuition fees, or they could obtain a grant, although that is also extremely rare. It is complicated!"

"Very possibly. But do not lose time trying to track every case, or every exception," he said. Standardized tests, as a dispositiff5 of power, govern students into engaging in the practices of a highly competitive system ${ }^{58}$ within a regime of truths in which accountability and consumerism are a safe bet for securing quality in education"

"Disruptions and disorders are needed!59" said I.

"Most likely. But there is no escape from the productive side of power" Chile succeeded in creating a system in which economic stability can be translated into better opportunities in life ${ }^{61}$. This success is translated into students being segregated according to their social and economic standing. The classroom is not only the place students are subjected; it is also where they are labeled. Labels that transcend their achievement as low-, average-, and high-performers, these labels express their social and economic standing. The classroom becomes a class/room," he said. "A low-income student is not directly excluded by policies, but subjected in the class/room to exclude him/herself and to render a resignation of what historically has been considered as success."

"Indeed, R.G. This is much more complex than the woman thinks it is."

"She is also subjected, dear Dr. M."

For many years, going to school was an investment. It was a consumer good with the essence of equity. For a long time, free school choice faded into economic policies leading to an era of consumerism of education: voucher and rewards system, excessive tuitions, expensive quality. "They disguised it by talking about welfare, but is all about a marketable system," the father said to himself, "What is welfare, anyways? What is welfare but a fancy word to obsess us about the future of our children." Competitiveness was the result of a group of people charmed by an ideal of optimizing economic benefit: the incepted neolib-

\footnotetext{
56 An example of this can be seen here: http://www.elpuclitico.cl/2011/08/29/yo-soyparte-de-la-clase-alta-chilena/

57 (Foucault, 1980).

58 (Andrade-Molina, 2017a).

59 For example the movement in mathematics education called The disorder of mathematics education (Straehler-Pohl, Bohlmann \& Pais, 2017; TME, 2018).

60 (Andrade-Molina, 2017a, p. 322).

61 (Andrade-Molina, 2017b, pp. 75-76).
} 
eral dreams. People charmed by the gains produced by citizens willing to consume education for a personal benefit. (Andrade-Molina, 2017b, pp. 42-43)

\section{References}

Andrade-Molina, M. (2017a). Not another typical story, yet not a new critique. A journey to utopia across evaluation in school. Educação UNISINOS, 21(3), 315-323. Andrade-Molina, M. (2017b). (D)effecting the child: The scientifization of the self through school mathematics. Published doctoral dissertation. Aalborg: Aalborg University Press. Andrade-Molina, M. (2017c). Incepted neoliberal dreams in school mathematics and the 'Chilean experience'. In T. Dooley, \& G. Gueudet, (Eds.). Proceedings of the tenth Congress of European Research in Mathematics Education (CERME10) (pp. 14251432). Dublin, Ireland: DCU Institute of Education and ERME.

Aravena, F., \& Quiroga, M. (2017). Early child care education: Evidence from the new law in Chile. Journal of Pedagogy, 8(1), 121-135.

Brooks, R. (2017). Education in Nordic countries. British Journal of Sociology of Education, 38(5), 753-760.

Cabalin, C. (2012). Neoliberal education and student movements in Chile: Inequalities and malaise. Policy Futures in Education, 10(2), 219-228.

Carrasco, A., \& Urrejola, A. (2017). La Agencia de Calidad de la Educación ¿Una política de evaluación integral? Revista Educación, Politica y Sociedad, 2(1), 8-26.

Cavieres, E. (2011). The class and culture-based exclusion of the Chilean neoliberal educational reform. Educational Studies, 47(2), 111-132.

Cotoi, C. (2011). Neoliberalism: A Foucauldian perspective. International Review of Social Research, 1(2), 109-124.

Deleuze, G. (1990). The logic of sense. New York: Columbia University Press.

Deleuze, G., \& Guattari, F. (1987). A thousand plateaus: Capitalism and schizophrenia. Minneapolis, MN: University of Minnesota Press.

Dussel, I. (2003). Educational policy after welfare: Reshaping patterns of governing children and families in Argentinean education. In M. Bloch, K. Holmlund., I. Moqvist., \& T. Popkewitz (Eds.), Governing children, families and education. Restructuring the welfare state (pp. 93-113). New York: Palgrave Macmillan.

Elacqua, G., Martinez, M., Santos, H., \& Urbina, D. (2016). Short-run effects of accountability pressures on teacher policies and practices in the voucher system in Santiago, Chile. School Effectiveness and School Improvement, 27(3), 385-405.

Foucault, M. (1980). Power/Knowledge: Selected interviews \& other writings 19721977. New York, Pantheon.

Foucault, M. (1988). Technologies of the self. In L. H. Martin, H. Gutman, \& P. H. Hutton (Eds.), Technologies of the self (pp. 16-49). Amherst: University of Massachusetts Press.

Höhne, T. (2006). Evaluation als Medium der Exklusion. Eine Kritik an disziplinärer Standardisierung im Neoliberalismus. In S. Weber, \& S. S. Maurer (Eds.), Gouvernementalität und Erziehungswissenschaft: Wissen-Macht-Transformation (pp. 197218). VS Verlag für Sozialwissenschaften. 
Kaščák, O., \& Pupala, B. (2011). Governmentality-Neoliberalism-Education: The Risk Perspective. Journal of Pedagogy, 2(2), 145-160.

Lee, I. (2012). Unpacking neoliberal policies: Interrupting the global and local production of the norms. Journal of Pedagogy, 3(1), 30-42.

Minarechová, M. (2012). Negative impacts of high-stakes testing. Journal of Pedagogy, 3(1), 81-100.

Miranda, F. (2017). Análisis del comportamiento especial de los resultados PSU. Revista CIS, 22, 63-85.

Mizala, A., \& Romaguera, P. (2000). School performance and choice: The Chilean experience. The Journal of Human Resources, 35 (2), 392- 417.

Popkewitz, T. (2015a). Numbers in telling educational truth. Fabrications of kinds of people and social exclusion. In T. Popkewitz (Ed.), The "reason" of schooling: Historicizing curricular studies, pedagogy, and teacher education (pp. 1-17). New YorkLondon: Routledge.

Popkewitz, T. (2015b). Curriculum studies, the reason of "reason", and schooling. In T. Popkewitz (Ed.), The "reason" of schooling: Historicizing curricular studies, pedagogy, and teacher education (pp. 150-166). New York-London: Routledge.

Popkewitz, T.S. (2009). The double gestures of cosmopolitanism and comparative studies of education. In R. Cowen, \& A. M. Kazamias (Eds.), International Handbook of Comparative Education. Springer International Handbooks of Education. Vol 22. Springer: Dordrecht.

Rambla, X., \& Veger, A. (2009). Pedagogising poverty alleviation: A discourse analysis of educational and social policies in Argentina and Chile. British Journal of Sociology of Education, 30(4), 463-477.

Rose, N. (1999). Powers of freedom: Reframing political thought. Cambridge, United Kingdom: Cambridge University Press.

Rose, N. (1996). Governing "advanced" liberal democracies. In A. Barry, T. Osborne, $\&$ N. Rose (Eds.), Foucault and Political Reason (pp. 37-64). London: Routledge.

Straehler-Pohl, H., Bohlmann, N., \& Pais, A. (Eds.). (2017). The disorder of mathematics education: Challenging the sociopolitical dimension of research. Switzerland: Springer.

TME (2018). TME Volume 15, Numbers 1 and 2: The disorder of mathematics education. Part II. The Mathematics Enthusiast, 15(1).

Wilkins, A. (2012). Pedagogy of the consumer: The politics of neo-liberal welfare reform. Journal of Pedagogy, 3(2), 161-173.

\section{Author:}

Melissa Andrade-Molina, Ph.D.

Graduate of the doctoral program at Aalborg University

Rendsburggade 14

Aalborg

9000

Denmark

Email: melissa.andrade.mat@gmail.com 